\title{
Response of Chronic Myeloid Leukemia's Patient to Different Types of Tyrosine Kinase Inhibitors
}

\author{
OSAMA A. IBRAHIM, M.D.*; RANIA M. HAFEZ, M.D.*; MARWA I. KHALAF, M.D.** and \\ MARWA A. MAHMOUD, M.Sc.* \\ The Departments of Internal Medicine* and Clinical Oncology**, Faculty of Medicine, Assiut University Hospital, Assiut, Egypt
}

\begin{abstract}
Background: Chronic Myeloid Leukemia (CML) is a proliferative neoplasm with an incidence of one to two cases per 100,000 adults. It accounts for approximately $15 \%$ of newly diagnosed cases of leukemia in adults, it is a serious and life-threatening condition, but with the introduction of tyrosine kinase inhibitors, there is much better life expectancy with low incidence of mortality and morbidity.
\end{abstract}

Aim of Study: Retrospective study to determine the response of CML patients to Imatinib and Nilotinib as a second lines of TKIS.

Patients and Methods: Records of CML patients who attended Assiut University Clinical Hematology Unit and Clinical Oncology Unit from 2014 to 2016 were revised and evaluated for complete hematological response, Partial Cytogenetic Response (PCR), Complete Cytogenetic Response (CCR) and Major Molecular Response (MMR).

The study evaluated the response of CML patients to two types of tyrosine kinase inhibitors; imatinib and Nilotinib as a second line therapy either by increasing the dose of imatinib $400 \mathrm{mg}$ to $800 \mathrm{mg}$ and Nilotinib $600 \mathrm{mg}$ to $800 \mathrm{mg}$ or shifting to the other line.

Results: Administration of Nilotinib $600 \mathrm{mg} /$ day or 800 $\mathrm{mg} /$ day achieved a higher percentage of MMR than imatinib $(p=<0.001)$.

Conclusion: Nilotinib is a selective efficient second line TKI drug after failure or tolerance to Imatinib as it is more effective than imatinib as a second line therapy either by increasing the dose or shifting to it regarding MMR with a $p$-value 0.04 .

The development of TKIs has changed the natural history of CML patients with improvement in the overall survival and life style.

Key Words: Chronic myeloid leukemia - Tyrosine kinase inhibitors - Major molecular response - Nilotinib - Imatinib.

Correspondence to: Dr. Marwa A. Mahmoud, The Department of Internal Medicine, Faculty of Medicine, Assiut University Hospital, Assiut, Egypt

\section{Introduction}

CHRONIC Myeloid Leukemia (CML) is a myeloproliferative disorder that occurs in all ages but predominates in adults with an incidence of one to two cases per 100,000 adults so It accounts for approximately $15 \%$ of newly diagnosed cases of leukemia in adults [1], the prevalence of CML in the United States, estimated at about 25-30,000 in 2000 , has increased to an estimated 80-1,00,0001 in 2015 , and will reach a plateau of about $1,80,000$ cases by 2030 [2].

CML is a clonal disorder diagnosed by leukemic cells, more than $95 \%$ of patients have a characteristic cytogenetic abnormality "the Philadelphia chromosome chromosome". It results from a reciprocal translocation between the long arms of both chromosomes 9 and 22 [3].

\section{It has three stages:}

1- Chronic phase: Patients in this phase typically have less than $10 \%$ blasts in their blood or bone marrow samples [4].

2-Accelerated phase: Patients have accelerated phase if any of the following are found; the bone marrow or blood samples have more than $10 \%$ but fewer than $20 \%$ blasts or high blood basophil count (basophils making up at least $20 \%$ of the white blood cells), high white blood cell counts that do not go down with treatment, very high or very low platelet counts that are not caused by treatment or new chromosome changes in the leukemia cells [5]

3-Blast phase (also called acute phase or blast crisis): Bone marrow and/or blood samples from a patient in this phase have more than $20 \%$ blasts. In this phase, the CML acts much like an aggressive acute leukemia [6] 
The diagnosis of CML is based on histopathologic findings in the peripheral blood and blood smear in a form of high total WBC count with slightly increased basophils and eosinophils, thrombocytopenia, thrombocytosis or it may be of normal platelete counts, Leukoerythroblastic reaction, with circulating immature cells from the bone marrow and early myeloid cells [7].

The bone marrow findings in the form of Hypercellularity with increase of the myeloid cell line and its precursor cells, Megakaryocytes are prominent may be increased or decreased and presence of Philadelphia chromosome in bone marrow studies [8].

Treatment of patients with Chronic Myelogenous Leukemia (CML) is usually initiated when the diagnosis is established, with the introduction of tyrosine kinase inhibitors as a definite treatment for CML the annual mortality in CML has decreased from $10-20 \%$ down to $1-2 \%$ [9].

\section{Tyrosine kinase inhibitors for CML:}

- Imatinib mesylate (Gleevec): For chronic, accelerated and blast phases (standard treatment of choice).

-Dasatinib (Sprycel): For chronic phase, accelerated and blast phases.

- Nilotinib (Tasigna): For chronic phase, accelerated and blast phases.

- Bosutinib (Bosulif): For chronic, accelerated, and blast phases.

- Ponatinib (Iclusig): For chronic or blast phase T315I-positive cases, or inappropriate patients in whom no other TKI therapy is tolerated or indicated [10].

In this study we evaluated the response of chronic myeloid leukemia patients to second line of tyrosine kinase inhibitors imatinib and nilotinib in different doses after failure or tolerance to first line therapy.

\section{Patients and Methods}

Retrospective study records of 140 CML patients who attended Assiut University Clinical Hematology Unit and Clinical Oncology Unit from 2014 to 2016 were revised and evaluated for response of second line tyrosine kinase inhibitors in form of complete hematological response, partial cytogenetic response, complete cytogenetic response and major molecular response.
The study evaluated the response of $140 \mathrm{CML}$ patients to two types of tyrosine kinase inhibitors; Imatinib and Nilotinib as a second line therapy either by increasing the dose of Imatinib $400 \mathrm{mg}$ to $800 \mathrm{mg}$ and Nilotinib $600 \mathrm{mg}$ to $800 \mathrm{mg}$ or shifting to another line.

Efficacy of the drug was evaluated at different four times during the therapy; at end of ${ }^{1 \text { st }}$ month to assess CHR, 3 rd month to assess PCR, 6 th to assess CCR and MMR was assessed during the 12 th month of therapy unless any responsive criteria was achieved from first line therapy.

\section{Criteria for responses:}

- A complete hematologic response includes the following:

- Complete normalization of peripheral blood counts, with a leukocyte count $<10 \times 10^{9} / \mathrm{L}$ and a platelet count $<450 \times 10^{9} / \mathrm{L}$.

- No immature cells (eg, myelocytes, promyelocytes, or blasts) in the peripheral blood.

- No signs and symptoms of disease; disappearance of palpable splenomegaly.

- A partial hematologic response is indicated by one or more of the following:

- Immature cells in the peripheral blood.

- Platelet count $<50 \%$ of the pretreatment count but $>450 \times 10^{9} / \mathrm{L}$.

- Persistent splenomegaly, but $<50 \%$ of the pretreatment extent.

- A complete cytogenetic response requires that there will be no $\mathrm{Ph}+$ metaphases.

- A partial cytogenetic response includes 1-35\% $\mathrm{Ph}+$ metaphases.

- A complete molecular response requires that BCR-ABL mRNA be undetectable by reverse transcriptase polymerase chain reaction (RTPCR).

- A major molecular response includes > $3 \log$ reduction of BCR-ABL mRNA.

Statistical analysis:

The results of the study were tabulated and statistical analysis was carried out using statistical package spss/pc Version 12 using significant level $(p<0.05)$

Continuous data will be expressed in form median and analyzed by using student $t$-test while nominal data will be expressed in form of frequency and proportion and compared by Chi square test. 


\section{Results}

The study evaluated response of CML patients to two different types of tyrosine kinase inhibitors; Imatinib and Nilotinib. The study included 140 patients were diagnosed to have CML. Patients were divided into two according to type of tyrosine kinase inhibitor was used as a first line of therapy; Imatinib group ( $400 \mathrm{mg} /$ day) that included 84 patients and Nilotinib $(600 \mathrm{mg} /$ day) group that included 56 patients.

Clinical and demographic data of the patients: Males were more frequent in both groups; 49 $(58.3 \%)$ patients inImatinib group and $30(53.6 \%)$ patients in Nilotinib group. Median age was 53 and 30 years for Imatinib and Nilotinib group respectively.

Median duration of the disease since diagnosis till last visit was 15 months in case of Imatinib group but in case of Nilotinib group was 14 months. Huge splenomegaly was found in $61(72.6 \%)$ patients who received Imatinib and in $30(57.1 \%)$ patients in case of Nilotinib group.

Majority of patients in both groups had low Sokal risk score for CML where $49(58.3 \%)$ and $21(37.5 \%)$ patients in Imatinib and Nilotinib group respectively had low Sokal risk score.

It was noticed that there were significant statistical differences between both groups respecting median age, splenomegaly and Sokal risk score where $p$-value was $0.00,0.03$ and 0.00 respectively. In contrast median of disease duration and sex of the patients had no significant statistical differences where $p$-value was 0.06 and 0.3 respectively.

Sixty five $(77.4 \%)$ patients in Imatinib group were in chronic stable phase of the disease but in case of Nilotinib group $30(53.6 \%)$ patients were in this phase. The results showed a statistical significant difference between Imatinib group and Nilotinib group regarding the phase of the disease with $p$-value was 0.02 .

Characteristics of patients who started second line of therapy (either increasing dose of 1 st line or shifted to other line):

Fifty three patients from those who not respond to the first line were shifted to the second line. All of those patients had CHR to 1 st line of therapy but failed to achieve the subsequent response.

Majority of them, 30 (57\%) patients, were on Imatinib in the 1 st line and $23(43 \%)$ patients were on Nilotinib $(p<0.04)$. There was no specific guide to type of second line either increasing dose of 1 st line or shifted to other agents where in $6(11.3 \%)$ patients dose of Imatinib was increased to $800 \mathrm{mg}$, 20 (37.7\%) patients dose of Nilotinib was increased into $800 \mathrm{mg}$ and $27(50.9 \%)$ patients were shifted to Nilotinib 600mg.

Regarding demographic and clinical data of those patients; only age was significantly differed between the three groups $(p=0.02)$ where those patients who received Imatinib $800 \mathrm{mg}$ were older than other patients. Other data as duration of disease, splenomegaly, and Sokal risk score were statistical insignificant variables between the three groups where $p$-value was $>0.05$.

\section{Outcome of 2 nd line of therapy:}

- Achievement of PCR: Only three patients didn't achieve PCR during 1 st line of therapy and shifted to 2 nd line; all of them achieved PCR with 2 nd line of therapy. All of those patients received Imatinib $800 \mathrm{mg} /$ day.

- Achievement of CCR: It was noticed that all patients on 2 nd line of therapy achieved CCR during their follow-up.

- Achievement of MMR: Out of 53 patients received 2nd line of therapy; $48(90.5 \%)$ patients achieved MMR with high percentage of achievement of MMR among those used Nilotinib 600mg/day $(p=0.00)$.

Five patients deteriorated and died; two of them had disease progression and were on Imatinib 800 $\mathrm{mg} /$ day and other three patients deteriorated due to adverse effect of therapy and were on Nilotinib 600 or $800 \mathrm{mg} /$ day.

Table (1): Clinical and demographic data of patients in the study.

\begin{tabular}{lccc}
\hline Characteristics & $\begin{array}{c}\text { Imatinib group Nilotinib group } \\
(\mathrm{n}=84)\end{array}$ & $\begin{array}{c}p \text { - } \\
\text { value }\end{array}$ \\
\hline Age (years) & $53(22-75)$ & $30(20-66)$ & 0.00 \\
Median duration (months) & $15(4-34)$ & $14(5-32)$ & 0.06 \\
Sex: & & & \\
$\quad$ Male & $49(58.3 \%)$ & $30(53.6 \%)$ & 0.3 \\
$\quad$ Female & $35(41.7 \%)$ & $26(46.4 \%)$ & \\
Splenomegaly: & & & \\
$\quad$ Huge & $61(72.6 \%)$ & $32(57.1 \%)$ & 0.04 \\
$\quad$ Moderate & $23(27.4 \%)$ & $24(42.9 \%)$ & \\
Sokal risk score: & & & \\
$\quad$ Low & $49(58.3 \%)$ & $21(37.5 \%)$ & 0.00 \\
$\quad$ Intermediate & $33(39.3 \%)$ & $26(36.4 \%)$ & \\
$\quad$ High & $2(2.4 \%)$ & $9(16.1 \%)$ & \\
\hline
\end{tabular}

- Data was expressed in form of median while nominal data was expressed in form of frequency (percentage).

$p$-value considered of statistical significance if <.05. 
Table (2): Different types of $2^{\text {nd }}$ line in the study.

\begin{tabular}{lccc}
\hline \multirow{2}{*}{ Second line } & \multicolumn{2}{c}{ First line } & Total \\
\cline { 2 - 4 } & Imatinib group & Nilotinib group & \\
\hline Increasing dose of Imatinib & 6 & 0 & 6 \\
Increasing dose of Nilotinib & 0 & 20 & 20 \\
Shifted to Nilotinib & 27 & 0 & 27 \\
\hline Total & 33 & 20 & 53 \\
\hline
\end{tabular}

Data was expressed in form frequency.

Table (3): Demographic and clinical characteristics of patients started $2^{\text {nd }}$ line therapy.

\begin{tabular}{|c|c|c|c|c|c|c|}
\hline \multicolumn{2}{|l|}{ Variables } & \multicolumn{2}{|c|}{$\begin{array}{l}\text { Imatinib } \\
800 \mathrm{mg} \\
(\mathrm{n}=6)\end{array}$} & $\begin{array}{l}\text { Nilotinib } \\
800 \mathrm{mg} \\
(\mathrm{n}=20)\end{array}$ & $\begin{array}{l}\text { Nilotinib } \\
600 \mathrm{mg} \\
(\mathrm{n}=27)\end{array}$ & $\begin{array}{c}p- \\
\text { value }\end{array}$ \\
\hline \multicolumn{2}{|l|}{ Age (years) } & \multicolumn{2}{|c|}{$54(40-75)$} & $36(20-66)$ & $50(20-70)$ & 0.02 \\
\hline \multicolumn{4}{|c|}{ Median duration (months) 14 (8-34) } & $15(12-30)$ & ) $13(10-34)$ & 0.08 \\
\hline $\begin{array}{l}\text { Sex: } \\
\quad \text { Male } \\
\text { Female }\end{array}$ & \multicolumn{3}{|c|}{$\begin{array}{l}4(66.67 \%) \\
2(33.33 \%)\end{array}$} & $\begin{array}{l}14(70 \%) \\
6(30 \%)\end{array}$ & $\begin{array}{l}15(55.6 \%) \\
12(44.4 \%)\end{array}$ & 0.58 \\
\hline $\begin{array}{l}\text { Splenomegaly: } \\
\text { Huge } \\
\text { Moderate }\end{array}$ & \multicolumn{3}{|c|}{$\begin{array}{l}4(66.67 \%) \\
2(33.33 \%)\end{array}$} & $\begin{array}{l}14(70 \%) \\
6(30 \%)\end{array}$ & $\begin{array}{l}24(88.9 \%) \\
3 \quad(11.1 \%)\end{array}$ & 0.21 \\
\hline $\begin{array}{l}\text { Sokal risk score: } \\
\text { Low } \\
\text { Intermediate } \\
\text { High }\end{array}$ & & $\begin{array}{l}0 \\
2(33 . \\
4(66 .\end{array}$ & $\begin{array}{l}3 \%) \\
7 \%)\end{array}$ & $\begin{array}{l}6(30 \%) \\
9(45 \%) \\
5(25 \%)\end{array}$ & $\begin{array}{ll}8 & (29.6 \%) \\
7 & (25.9 \%) \\
12 & (44.4 \%)\end{array}$ & 0.19 \\
\hline \multicolumn{7}{|c|}{$\begin{array}{l}\text { - Data was expressed in form of median while nominal data was } \\
\text { expressed in form of frequency (percentage). } \\
p \text {-value considered of statistical significance if }<.05 \text {. }\end{array}$} \\
\hline \multicolumn{7}{|c|}{$\begin{array}{l}\text { Table (4): Disposition of patients according to achievement } \\
\text { of PCR during }{ }^{\text {nd }} \text { line of therapy. }\end{array}$} \\
\hline Variables & & $\begin{array}{l}\text { tinib } \\
0 \mathrm{mg} \\
=6)\end{array}$ & & $\begin{array}{l}\text { lotinib } \\
00 \mathrm{mg} \\
\mathrm{n}=20)\end{array}$ & $\begin{array}{l}\text { Nilotinib } \\
600 \mathrm{mg} \\
(\mathrm{n}=27)\end{array}$ & $\begin{array}{c}p- \\
\text { value }\end{array}$ \\
\hline $\begin{array}{l}\text { - Achieve CCR } \\
\text { - Death } \\
\text { - Stoppage due to } \\
\text { adverse effects } \\
\text { - Lost follow-up }\end{array}$ & $\begin{array}{l}6(10 \\
0 \\
0\end{array}$ & $00 \%)$ & $\begin{array}{l}20( \\
0 \\
0\end{array}$ & $(100 \%)$ & $\begin{array}{l}27(100 \%) \\
0 \\
0\end{array}$ & $\begin{array}{l}0.67 \\
0 \\
0\end{array}$ \\
\hline
\end{tabular}

Data was expressed in form of frequency (percentage).

$p$-value was considered significant if $<0.05$.

Table (5): Disposition of patients according to achievement of MMR during $2^{\text {nd }}$ line of therapy.

\begin{tabular}{lllll}
\hline Variables & $\begin{array}{c}\text { Imatinib } \\
800 \mathrm{mg} \\
(\mathrm{n}=6)\end{array}$ & $\begin{array}{c}\text { Nilotinib } \\
800 \mathrm{mg} \\
(\mathrm{n}=20)\end{array}$ & $\begin{array}{c}\text { Nilotinib } \\
600 \mathrm{mg} \\
(\mathrm{n}=27)\end{array}$ & $\begin{array}{c}p \text { - } \\
\text { value }\end{array}$ \\
\hline - Achieve MMR & $4(66.7 \%)$ & $18(90 \%)$ & $26(96.3 \%)$ & 0.00 \\
- Death due to: & & & & \\
$\begin{array}{l}\text { Disease progression } \\
\text { Adverse effects }\end{array}$ & $2(33.3 \%)$ & 0 & 0 & 0.01 \\
$\quad \begin{array}{l}\text { Total } \\
\text { - Stoppage due to }\end{array}$ & 0 & 0 & 0 & \\
$\begin{array}{l}\text { adverse effects } \\
\text { - Lost follow-up }\end{array}$ & 0 & 0 & 0 & \\
\hline
\end{tabular}

Data was expressed in form of frequency (percentage). $p$-value was considered significant if $<0.05$.
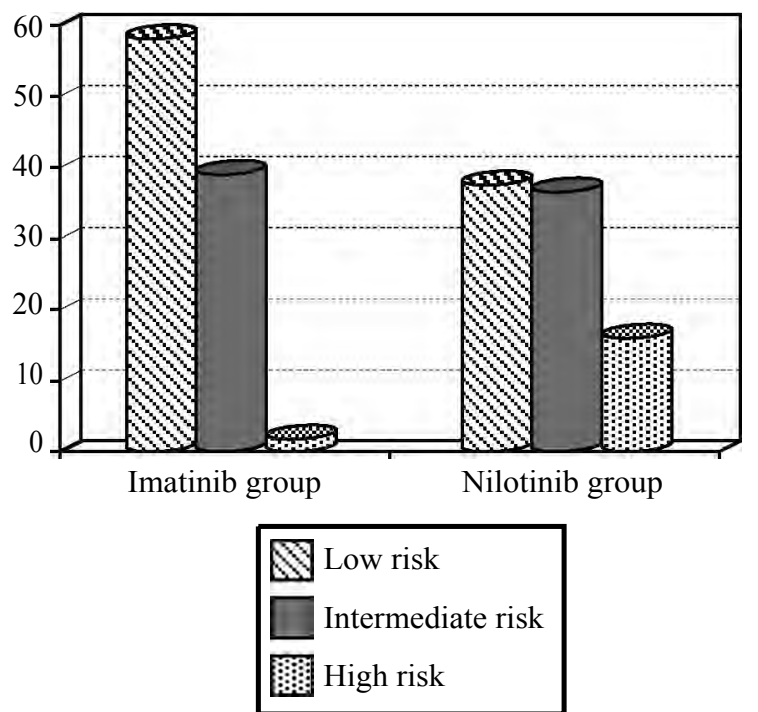

Fig. (1): Sokal risk score for all patients where data was expressed in form of percentage.

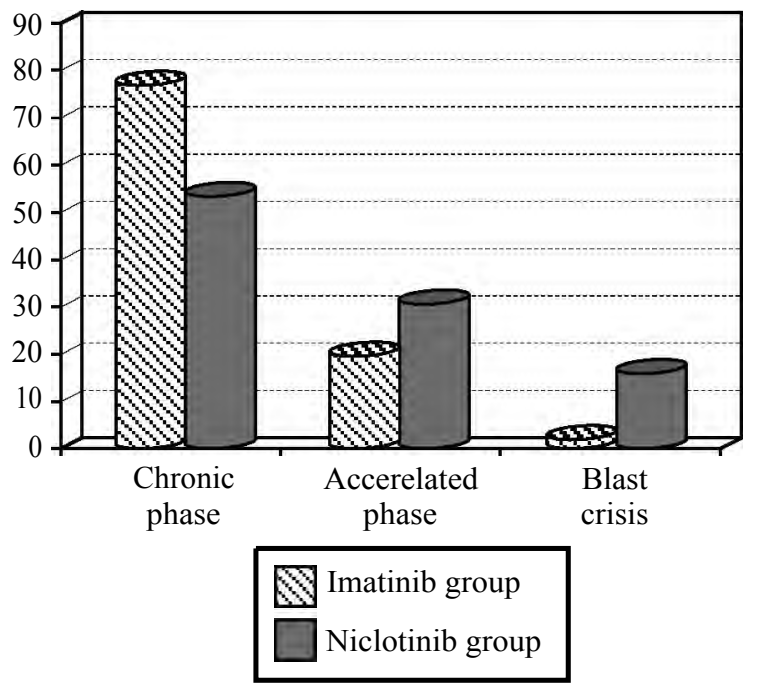

Fig. (2): Phases of CML in both groups where data was expressed in form of percentage.

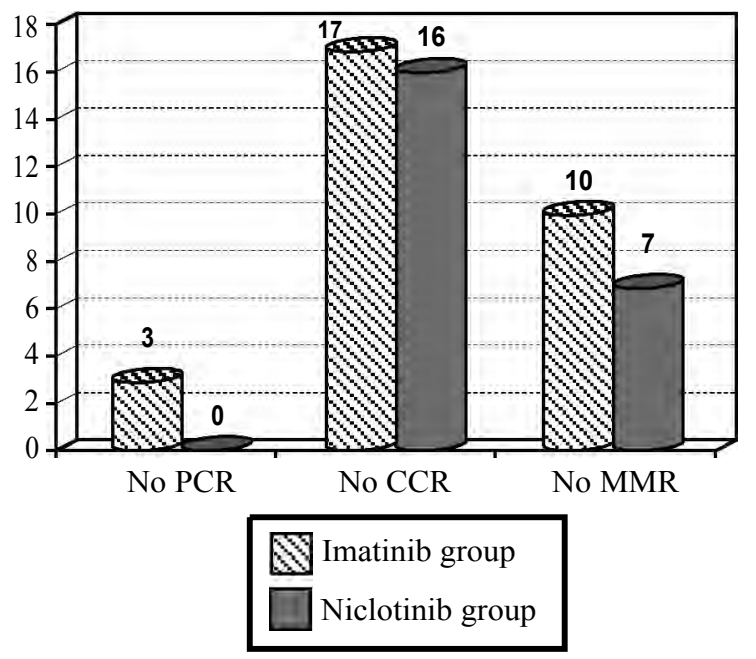

Fig. (3): Point of shifting to second line in the study where data was expressed in form of frequency. 


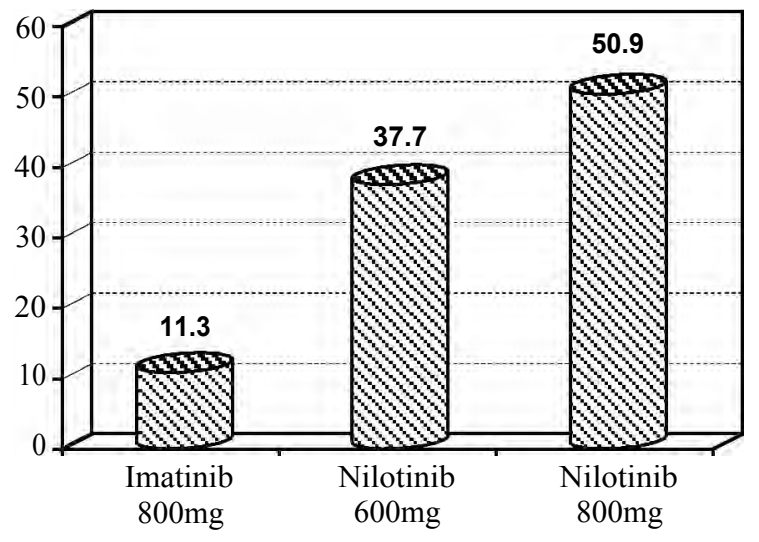

Fig. (4): Type of second line of therapy in the study where data was expressed in form of percentage.

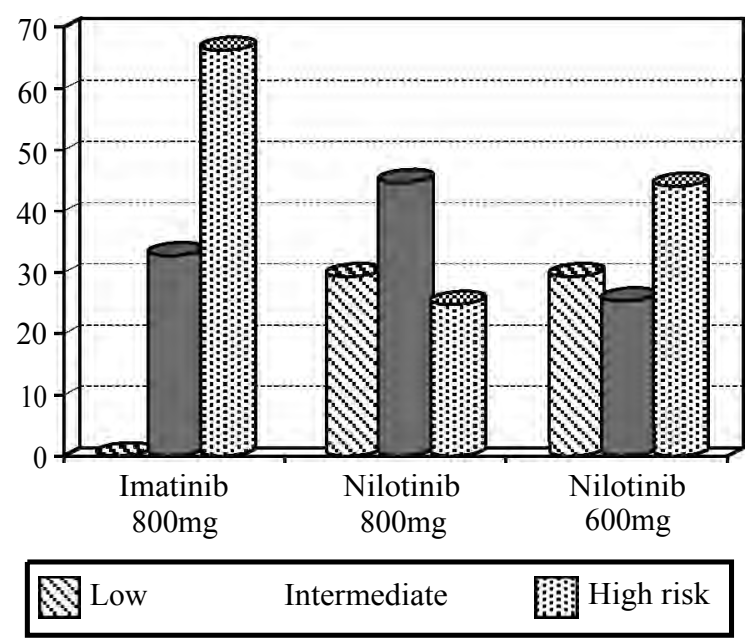

Fig. (5): Sokal score in patients on second line therapy where data was expressed in form of percentage.

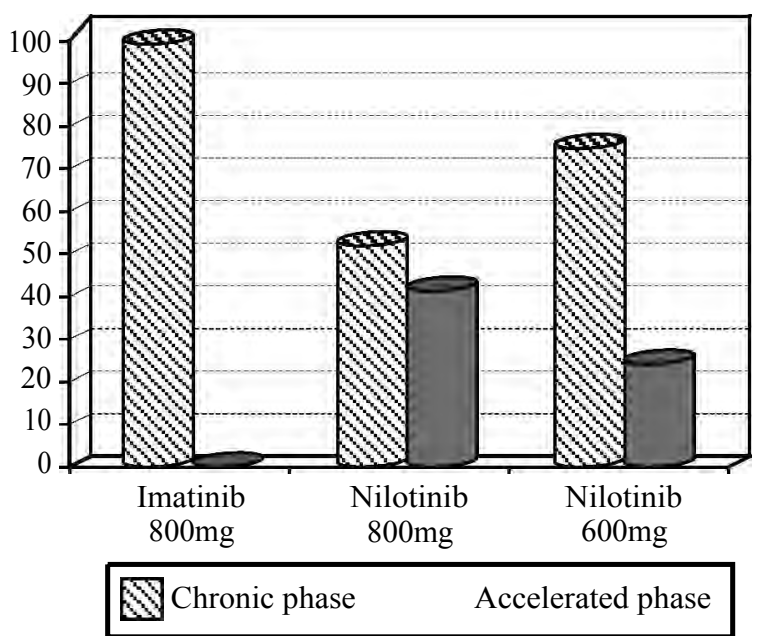

Fig/ (6): Phase of the disease in patients started second line therapy.

\section{Discussion}

The treatment of patients with CML who are intolerant of or have a primary or secondary resistance to a TKI will make choosing a second line treatment is mandatory (either increasing dose of 1 st line imatinib from $400 \mathrm{mg}$ to $800 \mathrm{mg}$ or nilotinib $300 \mathrm{mg}$ to $600 \mathrm{mg}$ or shifting to another line).

Our study included 140 patients diagnosed to have CML ph +ve at Clinical Hematology Unit Internal Medicine Department and Medical Oncology Department at Assuit University Hospital from 2014 to 2016.

We evaluated the response of CML patients to two different types of tyrosine kinase inhibitors; Imatinib and Nilotinib as a second line therapy.

Efficacy of the drug was evaluated at four different times during therapy; at end of 1 st month to assess CHR, 3 rd to assess PCR, 6 th to assess $\mathrm{CCR}$ and MMR was assessed during the 12 th month of therapy.

Fifty three patients from those who has not respond to the first line were shifted to the second line, in six (11.3\%) patients the dose of Imatinib was increased to $800 \mathrm{mg}$, in $20(37.7 \%)$ patients the dose of Nilotinib was increased to $800 \mathrm{mg}$ and $27(50.9 \%)$ patients were shifted to Nilotinib $600 \mathrm{mg}$.

In our study out of 53 patients who had received 2nd line therapy; 48 (90.5\%) patients had achieved MMR with high percentage of achievement of MMR among those who used Nilotinib $600 \mathrm{mg} / \mathrm{day}$ $(p=0.00)$ which is in agreement with Saglio et al., [11] who have reported that on the pivotal ENESTnd results from an international, phase III randomized open-label active-control multicenter study; the MMR rate at 12 months for nilotinib was $44 \%$ in the $300 \mathrm{mg}$ twice daily recipients and $43 \%$ for the 400mg twice daily recipients, with both MMR rates being nearly twice that seen in the imatinib treated patients $(22 \%$; $p$-value $<0.001$ for both comparisons).

It is supported also by Norbert Gattermann et al., [12] study which showed that major molecular response was achieved in 134 of 280 patients $(48 \%$; 95\% CI, $41.9 \%-53.9 \%$ ). Rates of major molecular response were $48 \%$ (95\% CI, $41.2 \%-55.7 \%$ ) in patients with imatinib intolerance and $47 \%(95 \%$ CI, 35.7\%-57.6\%) in patients with imatinib resistance.

In this current study, the responsive criteria of nilotinib is in agreement with the study of Hochhaus et al., [13] who showed that nilotinib has achieved a greater cumulative response rate than imatinib and also that the rates with nilotinib has grew faster than that of imatinib, this is in agreement also with Jorge E. Cortes et al., [14] who has suggested that 
Nilotinib is a front-line treatment for patients with chronic myeloid leukemia in early chronic phase and that Nilotinib is an effective option for the initial management of CML in early chronic phase, producing high rates of $\mathrm{CCyR}$ and MMR, with most patients reaching these responses early during their study, his study included 51 patients in chronic phase observed for at least 3 months, 50 (98\%) achieved a Complete Cytogenetic Remission (CCyR), and 39 (76\%) achieved a Major Molecular Response (MMR) which supports our study with a $p$-value $<0.05$.

\section{Conclusion:}

The development of TKIS has changed the natural history of CML patients with improvement in the overall survival and life style.

Imatinib mesylate and new TKIs along with allogeneic stem cell transplantation and other factors have contributed to the life expectancy in patients with CML approaching that of the general population today.

On the basis of this systematic study's results, among 140 patients of $\mathrm{ph}+\mathrm{ve} \mathrm{cml}$ nilotinib is an selective efficient second generation TKI drug after failure or tolerance to imatinib and it is more effective than imatinib as a second line therapy either by increasing the dose or shifting to it regarding MMR with a $p$-value 0.04 .

\section{Recommendations:}

We recommend further studies are needed to a wide group of patients to compare between both agents regarding efficacy, side effects and overall survival.

Administrative and financial facilities are needed for the patients in order to allow all the lines of treatment available to overwiden the options for treatment according to the patient's condition.

Fund: No fund has been received.

Conflict of interest: No conflict of interest could be declared.

\section{References}

1- LEITNER A.A., HOCHHAUS A. and MÜLLER M.C.: Current treatment concepts of CML. Curr. Cance. Drug. Targets., 11 (1): 31-43, 2013.

2- KANTARJIAN H., SAWYERS C., HOCHHAUS A., et al..: For the International STI571 CML Study Group. Hematologic and cytogenetic responses to imatinib mesylate in chronic myelogenous leukemia. N. Engl. J. Med., Feb. 28. 346 (9): 645-52, 2012.

3- KURZROCK R., KANTARJIAN H.M., DRUKER B.J., et al.: Philadelphia chromosome-positive leukemias: From basic mechanisms to molecular therapeutics. Ann. Intern. Med., 138 (10): 819-30, 2003.

4- CORTES J., ROUSSELOT P., KIM D.W., RITCHIE E., HAMERSCHLAK N., COUTRE S., HOCHHAUS A., GUILHOT F., SAGLIO G., APPERLEY J., OTTMANN O., SHAH N., ERBEN P., BRANFORD S., AGARWAL P. and GOLLERKERI A.: Dasatinib induces complete hematologic and cytogenetic responses in patients with imatinib-resistant or-intolerant chronic myeloid leukemia in blast crisis. Blood. 2007 Apr. 15, 109 (8): 3207-13. Epub 2006 Dec. 21.

5- DRUKER B.J. and MARIN D.: Chronic myelogenous leukemia. In: DeVita VT, Lawrence TS, Rosenberg SA, eds. DeVita. Hellman, and Rosenberg's Cancer: Principles and Practice of Oncology. 10 th ed. Philadelphia, Pa: Lippincott Williams \& Wilkins, 1644-53, 2015.

6- HEHLMANN R., BERGER U., PFIRRMANN M., HEIMPEL H., HOCHHAUS A., et al.: Tolerability-adapted imatinib $800 \mathrm{mg} / \mathrm{d}$ versus $400 \mathrm{mg} / \mathrm{d}$ versus $400 \mathrm{mg} / \mathrm{d}$ plus interferon- $\alpha$ in newly diagnosed chronic myeloid leukemia. J. Clin. Oncol., Apr. 20; 29 (12): 1634-42, 2011.

7- KANTARJIAN H., SAWYERS C., HOCHHAUS A., et al.: For the International STI571 CML Study Group. Hematologic and cytogenetic responses to imatinib mesylate in chronic myelogenous leukemia. N. Engl. J. Med., Feb. 28, 346 (9): 645-52, 2012.

8- BACCARANI M., SAGLIO G., GOLDMAN J., et al.: Evolving concepts in the management of chronic myeloid leukemia: Recommendations from an expert panel on behalf of the European Leukemia Net. Blood., 108: 180920, 2006.

9- SIEGEL R., JEMAL A., XU J., et al.: Cancer statistics, 2010. CA Cancer J. Clin., 60: 277-300, 2010.

10- GOLDMAN J.M. and DRUKER B.J.: Chronic myeloid leukemia: Current treatment options. Blood, Oct. 1, 98 (7): 2039-42, 2011.

11- SAGLIO G., DONG-WOOK K., ISSARAGRISILL S., et al.: Nilotinib versus imatinib for newly diagnosed Chronic Myeloid Leukemia. N. Engl. J. Med., 362 (24): 2251-9, 2010a.

12- NORBERT G., CARLO F., MATTEO D.P., PIERRE F., MICHAEL S., AGNES G.B., MATHIAS S., KERRY T., DOMINIQUE V., DANY H., ANDREA M., BERNARD R. and CHRISTIAN R.: Hematologic responses to deferasirox therapy in transfusion-dependent patients with myelodysplastic syndromes. Haematologica, Sep., 97 (9): 1364-71, 2012.

13- HOCHHAUS A., SAGLIO G., HUGHES T.P., LARSON R.A., KIM D.W., ISSARAGRISIL S., LE COUTRE P.D., ETIENNE G., DORLHIAC-LLACER P.E., CLARK R.E., FLINN I.W., NAKAMAE H., DONOHUE B., DENG W., DALAL D., MENSSEN H.D. and KANTARJIAN H.M.: Long-term benefits and risks of frontline nilotinib vs imatinib for chronic myeloid leukemia in chronic phase: 5-year update of the randomized ENESTnd trial. Leukemia, May, 30 (5): 1044-54, 2016.

14- JORGE E. CORTES, DONG-WOOK KIM, JAVIER PINILLA-IBARZ, PHILIPP D., et al.: Evaluation of the Benefit/Risk Profile of Ponatinib in CP-CML Patients over Time: 4-Year Follow-up of the Phase 2 PACE Study. Blood, 126: 5142, 2015. 


\section{إستجابة مرضى اللوكيميا الميلودية المزمنة للآنواع المختلفة من مثبطات التايروزين كايناز}

سرطان الدم اللوكيمى المزمن هـ إضطراب تكاثر نقوى يؤثثر على مقصورة الخلايا الجذعية الكونة للدم. ويمكن آن يحدث في جميع الفئات

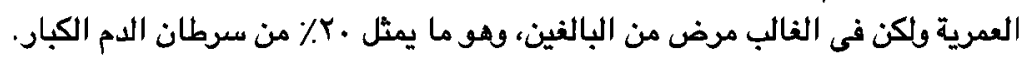

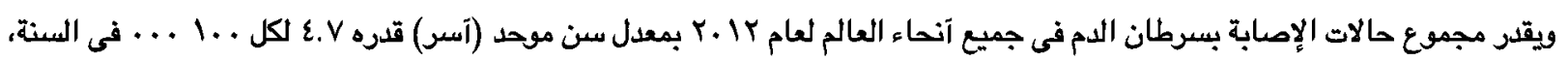

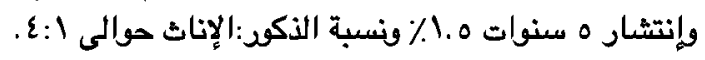

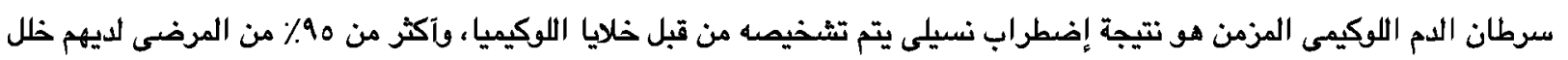

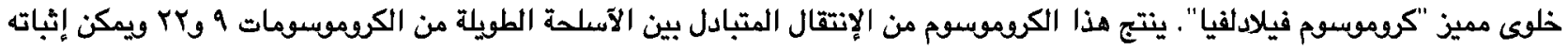

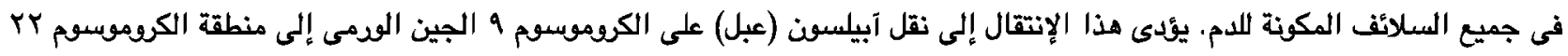

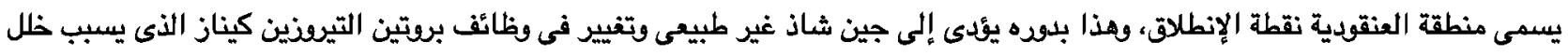

النخاع والإصابة بالمرض.

ويستند التشخيص على نتائج التشريح المرضى فى الدم المحيطى وفيلادلفيا (ف) كروموسوم فى خلايا نخاع العظام ويتكن من صودة دم كاملة وطاخة دم طرفية وتحليل نخاع عظمى.

من آهم وسائل علاج مرض إبيضاض الدم النقوى المزمن هى مثبطات التيروسين كايناز.

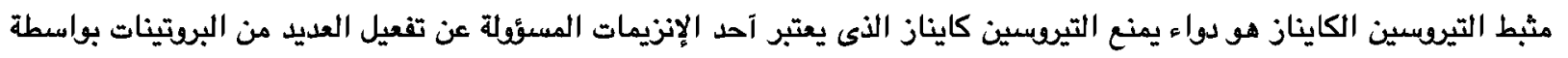

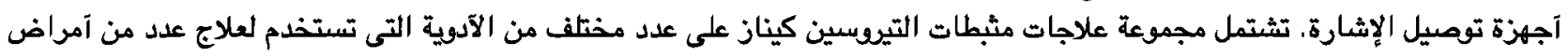

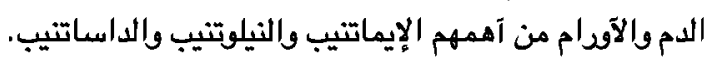

هدف الرسالة: دراسة إستعادية لتقيّم إستجابة مرضى اللوكيميا الميلوديه المزمنة لآنواع مختلفة من مثبطات كيناز التيروذين.

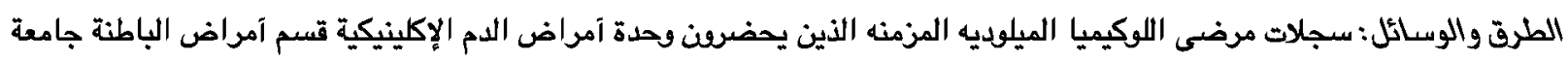

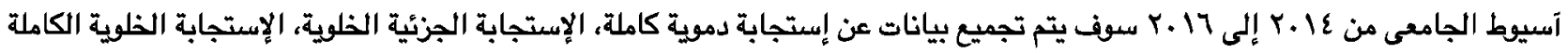
والإستجابة الجزيئية الرئيسية.

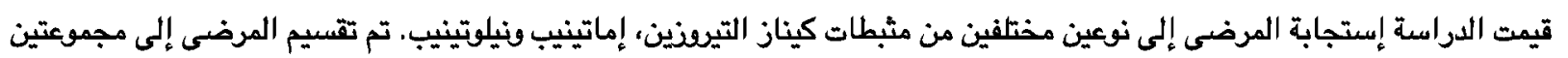

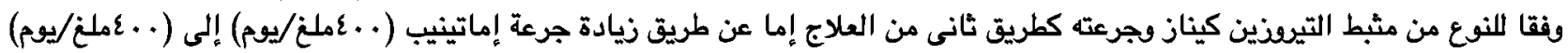

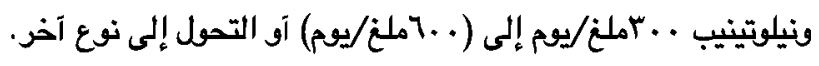

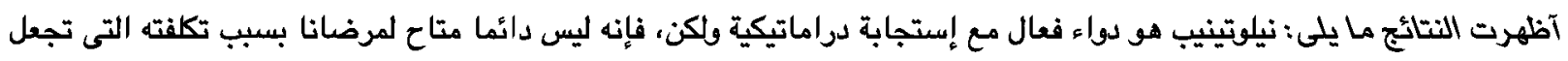
إستخدامه يقتصر على آن يكون السطر الثانى بعد فشل دلفين إماتينيب. 